\title{
Sartre as prosecutor of occupational murder: \\ notes from a People's Tribunal in a French mine (1970)
}

\author{
Pascal MARICHALAR \\ Gerald MARKOWITZ \\ David ROSNER
}

\section{Introduction}

On February 4, 1970, in the Fouquières-lès-Lens coal mine in northern France, sixteen miners were killed in a gas explosion (“firedamp," grisou in French). ${ }^{1}$ This was an accident like many others before it, yet with a relatively high number of fatalities. The public prosecutor concluded, as usual, that there was no case against the publicly owned mine. No investigation was to be carried out. The accident had been the work of fate, of bad luck.

Yet at the same time, the mine’s head engineers secretly launched an internal safety review, to ascertain what had technically gone wrong and what could be improved for the future. This discrepancy_claiming no investigation was necessary, while carrying one out in a confidential fashion—was too much for some engineers linked to the Maoist movement, who publicly denounced it.

On February 16, Maoist activists, from movements such as the Gauche Prolétarienne (Proletarian Left) and Secours Rouge (Red Rescue), armed with Molotov cocktails launched an attack on the head offices of the state-owned coal mines in Hénin-Liétard. Arrests followed. The trial of seven men was set for the following December. To the leftist organizations involved, the

1 Jean Bérard, “Tordre ou briser le bâton de la justice ?” Champ pénal/Penal field Vol. X, 2013; Vanessa Codaccioni, « Justice populaire et mimétisme judiciaire. Les maoïstes dans et hors la Cour de sûreté de l’État », Droit et société 2015/1 (89): 17-33. 


\section{Pre-print. For quoting please refer to the published version in International Labor and Working-} Class History (2021), 99, 167-176 doi:10.1017/S0147547921000016

contrast between the rush to prosecute the angry arsonists and the absence of any investigation concerning the mining accident was a blatant sign of a class justice system, rigged against the exploited masses.

The Maoists decided to take justice into their own hands. On December 12, 1970, the Gauche Prolétarienne organized a People’s Tribunal in a large room of Lens City Hall, before an audience of five hundred. The jury was asked what, or who, was responsible for the death of the sixteen miners. Colleagues of the deceased, as well as sympathetic engineers and physicians, were called upon to testify.

The mining industry as a whole was on trial. During the eighteenth and especially nineteenth centuries, throughout Europe and North America, mining had become central, providing the raw material for the Industrial Revolution. In the early part of the twentieth century, mine accidents and explosions killed thousands of miners every year. In the United States, more than three in every thousand miners died on the job every year, more than twice the mortality rate in England, France, or Germany. ${ }^{2}$ On both continents, mining became the symbol for the exploitation of the economic systems as a whole.

The Popular Tribunal's proceedings were centered not just on accidental hazards, such as firedamp or collapse, but also on silicosis, a disease that was most closely identified with mining. As historian Paul-André Rosental writes: “Silicosis is an incurable lung disease caused by inhaled silica dust, affecting not only miners, but also workers in quarries, foundries, glass and porcelain factories, in construction and in public works. Though the disease is now disappearing from national memory, it was the twentieth century’s most deadly occupational disease in France.”3 Similarly, in the United States silicosis was known as a "king of occupational diseases" for it

\footnotetext{
2 Arthure B. Reeve, “The Death Roll of Industry.” Charities and the Commons 17 (1907): 791.

3 Paul-André Rosental, "Before asbestos, silicosis. Death from occupational disease in twentieth-century France.” Population and Societies 437 (2007).
} 
affected workers in such a wide variety of industries and so completely captured the exploitation that was manifested by death and disease on the job. ${ }^{4}$

The People’s Tribunal in Lens was followed by the media, in part because of the status of the man who was acting as prosecutor: none other than Jean-Paul Sartre, who had taken over leadership of the Gauche Prolétarienne during the year 1970 after the previous leaders had been arrested. Sartre put on trial, not only the management of the mine but also the whole system implemented in 1898 to give a pretense of fairness to the harm that was being inflicted: While workers and their families received only meagre financial compensation for occupational injuries, diseases or fatalities, those profiting from the system-owners and managers—-were not held accountable. ${ }^{5}$ This administrative-managerial complex was the entity in France that the Maoist activists called out as the Boss-State (L'Etat-Patron). Debates turned in particular around the notion of a "percentage of silicosis," which was a bureaucratic category rather than a medical one. The "percentage of silicosis” determined the amount of compensation miners would receive. For example, it was common practice that some miners were "recognized” as having " $0 \%$ silicosis," an oxymoron that meant that though sick, they were not considered sick enough (yet) to claim any compensation.

Sartre's analysis was equally applicable to the system that was evolving in the United States. Beginning in the 1930s, states integrated silicosis and other dust diseases of long latency like asbestosis into their workers compensation schemes formally eliminating the need to assign blame or responsibility to negligent owners. Further, the compensation decisions were moved out of courtrooms and into the province of experts, primarily doctors, who, like in France, evaluated the degree of disability caused by the work. In the United States, the designation of "primary” silicosis served the same function as did “0 percent” silicosis in France. The workers’ compensation system

4 David Rosner and Gerald Markowitz, Deadly Dust: Silicosis and the Politics of Occupational Disease in Twentieth Century America (Princeton University Press, 1991)

5 Michael Behrent, “Accidents Happen: François Ewald, the “Antirevolutionary” Foucault, and the Intellectual Politics of the French Welfare State.” The Journal of Modern History 82 (3, 2010): 585-624. 
defined primary silicosis as a condition that caused scarring of the lungs (fibrosis) that was permanent but ineligible for compensation because it did not yet interfere with work. Thus, a workers’ body could be damaged but neither legal nor financial liability accrued to the owner. The worker's body was valued only as long as it labored.

As an existentialist philosopher, Sartre was famous for his notion of "bad faith" (mauvaise foi), i.e., the tendency to negate one's own freedom and to attribute one's actions to external forces. While Sartre’s idea was initially conceptualized in a metaphysical sense, he increasingly applied it to moral and political issues. The fundamental distinction between existence and essence was synonymous with freedom, and freedom entailed responsibility. Hence, Sartre was probably the best equipped intellectual to launch a critique of the no-fault, no-responsibility compensation scheme for occupational damages. The implementation of this scheme in 1898 had been synonymous with the end of all criminal prosecution of occupational damages, as if the notions of penal responsibility and guilt no longer had currency.

Sartre's critique would have been equally applicable to conditions in the UnitedStates, where the question of responsibility was also relegated to civil courts and not defined as subject to criminal prosecution. ${ }^{6}$ While political and economic leaders deemed workers' suffering as one of the "costs" of industrial "progress," socialists saw these diseases, disabling injuries, and deaths differently. Morris Hillquit of the US Socialist Party had anticipated Sartre's argument in 1911. At a mass gathering of workers, Hillquit protested “against the wanton and ceaseless murder of our sons and daughters in factories, mines, and mills.” He told the crowd that "if the capitalist class cannot conduct the industries of the country without murder the workers will assume management of the industries and conduct them with safety to the employees and for the good of the community."”

6 David Rosner, “When Does a Worker’s Death Become Murder?” American Journal of Public Health 90 (April, 2000): 535-40.

7 Quoted in “The Responsibility is on All Citizens,” The Survey 26 (April 8, 1911): 85. 


\section{Pre-print. For quoting please refer to the published version in International Labor and Working-}

Class History (2021), 99, 167-176 doi:10.1017/S0147547921000016

Two days after the Popular Tribunal, the State’s Safety Court (Cour de sûreté de l'Etat)—a special court originally designed to handle national security cases during the Algerian liberation waracquitted all the Maoist activists involved in the firebombing of the Head Offices, except for one of them, Bernard Liscia, who was sentenced in absentia.

Reproduced below is Sartre's closing speech as a prosecutor for the Popular Tribunal. It was published the following year in a collection of his interventions, ${ }^{8}$ yet this is the first time it is translated into English. Sartre’s words resonate with Edwin Sutherland's 1959 discussion of whitecollar crime, which is characterized by the fact that it is seldom prosecuted or punished. ${ }^{9}$ The existentialist perspective on occupational hazards helps address a fundamental question: Why is occupational injury, disease, and fatality rarely investigated and treated as a criminal matter? Sartre’s words also resonate with recent legal developments in asbestos criminal trials in Italy, which attempted to reinject a notion of responsibility, fault, and intention into these issues. ${ }^{10}$ Sartre raises the fundamental question: If death could be prevented and predicted by management, then was it not homicide? In this context, is there such a thing as an "accident”? Sartre raised these issues in the context of a mine disaster and framed it as a gross abdication of human rights, yet his argument was broader and more poignant, for it spoke to the pain that capitalists in their rush to industrialize had wrought upon the working masses.

The issues that Sartre raised in the context of the mining disaster a half century ago are equally relevant today. In the midst of the economic crisis created by the COVID-19 pandemic, our corporate and political leaders urged the opening of the economy despite the consensus among public health workers that sending workers back into factories and other commercial settings unprotected and untested is a cost that has to be paid to get business back to normal. As Sartre

8 Jean-Paul Sartre, “Premier procès populaire à Lens,” Situations VIII, Gallimard, 1971: 319-31.

9 Edwin H. Sutherland, White-Collar Crime: The Uncut Version, Yale University Press, 1985.

10 Pascal Marichalar, "How to Judge Safety Crime: Lessons From the Eternit Asbestos Maxi-Trials," New

Solutions: A Journal of Environmental and Occupational Health Policy, 2019. 
Pre-print. For quoting please refer to the published version in International Labor and WorkingClass History (2021), 99, 167-176 doi:10.1017/S0147547921000016

exposed all too precisely, it is workers, not those profiting from their labor, who are called upon to sacrifice their lives. 


\author{
Prosecution Closing Speech \\ by Jean-Paul Sartre, December, 1970. \\ Translation from the French: Pascal Marichalar
}

OPENING LINES

« We must decide whether the disaster is due to bad luck.

If the accident could have been prevented and was not, then we are dealing with homicide. There are two types: negligent homicide and intentional homicide. In this case, we must decide which of these two offences we are dealing with.

Nothing can be decided about the February 4 disaster without placing it within the general framework of safety.

The mine is foul, we are told; when the worker gets to the bottom, he is at danger of death, or at least of disability. He thinks these are hazards. If one day, bad luck causes him to lose his finger or his hand, he will easily have fallen victim to fate. This belief is only subjective and individual: no one can be sure of being injured this week, or this year. What is certain, however, is that there have been 80 deaths per year in recent years in all the mines in the North, and that there will be as many this year, if not more, because with the new machines, the number of accidents will increase. The managers and the engineers have the data. They know this for certain. Yet what do these percentage rates stand for? Some say, inevitability: “mines eat men”, they claim. (...)»

\title{
(All rights reserved Gallimard)
}

(originally published in French in Jean-Paul Sartre, Situations VIII, Gallimard, 1971, p. 319-331) 